\title{
LITERATURE REVIEW : EFEKTIVITAS PENGGUNAAN MEDIA PROMOSI KESEHATAN TERHADAP PENGETAHUAN DAN POLA KONSUMSI ZAT BESI PADA REMAJA
}

\author{
Monica Theresia Magdalena $N^{1}$,Haripin Togap Sinaga ${ }^{2}$ \\ Poltekkes Kemenkes Medan, Jurusan Gizi ${ }^{12}$ \\ e-mail: ${ }^{1}$ monicatheresiamn10@gmail.com, ${ }^{2}$ haripinsinaga@yahoo.com
}

\begin{abstract}
Adolescence is a period of transition from childhood to adulthood, which is marked by physical, physiological, and psychosocial changes. The level of knowledge in adolescents will affect attitudes and behavior in choosing food at school and at home. Efforts to improve the quality of life and better knowledge of adolescents can be made by utilizing appropriate, interesting and easy-to-understand media as a way to improve health services.

The purpose of this study was to determine the effectiveness of the use of health promotion media on knowledge and patterns of iron consumption in adolescents. The research method used the Literature Review method with secondary data collection from scientific research articles from 2015-2020. The data search used the Google Scholar database, Mendeley, DOAJ and Garuda Portal online using key words, namely health promotion media, knowledge, iron consumption patterns, adolescents. The articles are then evaluated according to their purpose, method and to review similarities and differences among them.

From 11 results of this Literature Review, there were 8 literature which stated that there was a significant increase in the use of health promotion media for knowledge $(p<0.05)$ after being given the intervention. There were 2 out of 3 Literature Reviews which showed that there was no effectiveness of health promotion media use on iron consumption patterns with a significant value $(p>0.05)$ after being given the intervention.
\end{abstract}

Keywords: Health Promotion Media, Knowledge, Iron Consumption Pattern, Adolescents

\begin{abstract}
ABSTRAK
Masa remaja adalah masa peralihan dari masa kanak-kanak ke usia dewasa, dimana ditandai oleh perubahan fisik, fisiologis,dan psikososial. Tingkat pengetahuan pada remaja akan berpengaruh terhadap sikap dan perilaku dalam memilih makanan disekolah maupun dirumah. Upaya untuk meningkatkan kualitas hidup dan pengetahuan remaja yang lebih baik dapat dilakukan dengan pemanfaat media yang tepat, menarik dan mudah dipahami sebagai salah satu cara meningkatkan pelayanan kesehatan.

Tujuan penelitian ini untuk mengetahui efektivitas penggunaan media promosi kesehatan terhadap pengetahuan dan pola konsumsi zat besi pada remaja. Metode penelitian menggunakan metode Literatur Review dengan pengumpulan data sekunder dari artikel penelitian ilmiah dari tahun 2015-2020. Pencarian data menggunakan database Google Scholar, Mendeley, DOAJ dan Portal Garuda secara online dengan menggunakan kata-kata kunci yakni media promosi kesehatan, pengetahuan, pola konsumsi zat besi, remaja. Artikel - artikel kemudian dievaluasi berdasarkan tujuan, metode dan untuk meninjau kesamaan dan perbedaan di antara artikel artikel tersebut.

Dari 11 hasil Literatur Review ini, terdapat 8 literatur yang menyatakan bahwa terdapat efektivitas penggunaan media promosi kesehatan terhadap pengetahuan yang mengalami peningkatan yang signifikan $(\mathrm{p}<0,05)$ setelah diberi intervensi.Terdapat 2 dari 3 Literatur Review yang menunjukkan bahwa tidak terdapat efektivitas penggunaan media promosi kesehatan terhadap pola konsumsi zat besi dengan nilai signifikan $(\mathrm{p}>0,05)$ setelah diberi intervensi.
\end{abstract}

Kata Kunci : Media Promosi Kesehatan, Pengetahuan, Pola Konsumsi Zat Besi, Remaja

\section{PENDAHULUAN}

\section{Latar Belakang}

Anemia merupakan masalah gizi yang umum terjadi di dunia, terutama di negara berkembang. Diperkirakan lebih dari $30 \%$ penduduk dunia atau 1500 juta orang menderita anemia dan sebagian besar tinggal di daerah tropik.Anemia defisiensi zat besi merupakan masalah gizi yang paling lazim di dunia dan menjangkiti lebih dari 600 juta manusia.

Prevalensi anemia secara global adalah sekitar 51\% (Kadir, 2016).

Berdasarkan hasil Riskedas 2013, prevalensi anemia di Indonesia yaitu $21,7 \%$ dengan penderita 
anemia berumur 5-14 tahun sebesar $26,4 \%$ sedangkan penderita anemia berumur 15-24 tahun sebesar 18,4\% dengan proporsi tempat tinggal $20,6 \%$ diperkotaan dan $22,8 \%$ di pedesaan serta $23,9 \%$ pada perempuan. Prevalensi anemia pada remaja $27 \%$ di negara-negara berkembang dan 6\% di negara maju (Suryani, 2015).

Remaja adalah individu baik perempuan maupun laki-laki yang berada pada usia antara anak-anak dan dewasa. Batasan remaja dalam hal ini adalah usia 10 sampai 19 tahun menurut klasifikasi World Health Organization (WHO,2014).Masa remaja (adolesen) masa peralihan dari masa kanak-kanak ke usia dewasa, dimana ditandai oleh perubahan fisik, fisiologis,dan psikososial. Ciri khas dari masa remaja adalah adanya kematangan fungsi seksual, pacuh tumbuh (growth spurt) dan tercapainya bentuk tubuh dewasa, yang terjadi karena pematangan fungsi endokrim (Kadir, 2016) . Masa remaja merupakan suatu massa transisi dari masa kanak-kanak kemasa dewasa dengan batas usia 10-18 tahun, dimana secara fisik akan mengalami perubahan spesifik dan secara psikologi akan mulai mencari identitas diri (Ningsih, 2018).

Tingkat pengetahuan pada remaja akan berpengaruh terhadap sikap dan perilaku dalam memilih makanan disekolah maupun dirumah. Penyuluhan gizi sangat penting dalam meningkatkan pengetahuan remaja tentang makanan dan mengubah kebiasaan makan remaja (Sediaoetama, 2000). Konsumsi zat gizi yang tidak seimbang baik kekurangan maupun kelebihan akan menurunkan kualitas sumber daya manusia (Juliani, 2018).

Zat besi merupakan salah satu mineral makro yang penting dalam pembentukan sel darah merah yang diperoleh dari makanan. Zat besi berfungsi bagi tubuh untuk membawa oksigen dan karbondioksida dalam pembentukan darah. Selain itu berfungsi sebagai komponen penyusun dari beberapa enzim berperan di dalam produksi energi, produksi antibody, dan untuk detoksifikasi zat racun dalam hati (Kesuma,2012).

Kekurangan zat besi akan menyebabkan penurunan sistem imun, gangguan perkembangan psikomotor dan menurunkan kemampuan kerja Kekurangan selama siklus haid juga akan menyebabkan remaja putri terkena penyakit Anemia Gizi Besi (Suarjana, 2017). Anemia gizi besi yang terjadi pada remaja dipengaruhi oleh ketersediaan bahan panga, pola makan yang salah, menurangi jumlah makanan yang dikonsumsi karena faktor ingin langsing (Marmi,2013).

Promosi kesehatan adalah salah satu bentuk upaya dalam pelayanan kesehatan yang berdasarkan pada penyampaian pesan atau informasi tentang kesehatan sebagai penanaman pengetahuan mengenai kesehatan, sehingga muncul kesadaran akan hidup sehat (Kholid, 2012). Untuk mencapai sasaran dalam promosi kesehatan, maka diperlukan strategi sebelum menjalankan promosi kesehatan. Strategi dari promosi kesehatan tersebut terdiri dari, advokasi, dukungan sosial, dan juga pemberdayaan masyarakat. Baik rumah sakit umum maupun rumah sakit jiwa perlu adanya promosi kesehatan dengan ketiga strategi tersebut, supaya masyarakat dapat menanamkan rasa kesadaran akan hidup bersih dan sehat.

Meningkatkan pengetahuan, sikap dan perilaku perlu adanya pemberian informasi yang menurut WHO merupakan salah satu strategi untuk memdapatkan perubahan perilaku. Salah satu upaya pemberian informasi adalah dengan menggunakan media promosi kesehatan. Media promosi kesehatan akan sangat membantu agar pesan-pesan yang disampaikan dalam promosi kesehatan dapat diberikan dengan jelas sehingga sasaran dapat menerima pesan dengan jelas dan tepat yang dapat terlihat dengan terjadinya peningkatan nilai pengetahuan (Notoaatmodjo, 2010).

Literasi kesehatan pada hakikatnya merupakan kemampuan seseorang untuk memperoleh, memproses dan memahami informasi serta kebutuhan akan pelayanan yang dibutuhkan dalam pengambilan keputusan yang tepat. Literasi kesehatan mutlak membutuhkan informasi kesehatan. Sedangkan informasi kesehatan dapat diperoleh dari berbagai sumber informasi seperti media cetak, media massa, media elektronik (Institute of Medicine, 2004).

\section{Tujuan Penelitian}

Mengkaji tentang Efektivitas Media Promosi Kesehatan terhadap pengetahuan dan pola konsumsi zat besi pada remaja dengan melakukan kajian pustaka dari artikel ilmiah yang terbit pada jurnal nasional terindeks.

\section{METODE}

Desain penelitian yang digunakan dalam studi ini adalah kajian pustaka (Literature review), yaitu melakukan penelusuran terhadap artikel ilmiah dengan cara membaca, meringkas, membandingkan dan melakukan kritik serta memberikan pendapat. Data yang digunakan bersumber dari artikel ilmiah. Pencarian artikel menggunakan data base jurnal yaitu Google Scholar, Mendeley, DOAJ, dan Portal Garuda. Pencarian menggunakan kata kunci (key words) media promosi kesehatan tentang pengetahuan dan polakonsumsi zat besi pada remaja. Jika artikel yang diperoleh tidak sesuai maka kata kunci diganti dengan "media promosi kesehatan pada remaja" .Literature Review ini menggunakan literature terbitan tahun 2015 - 2019 atau rentang waktu penerbitan jurnal maksimal 5 tahun. Penulis harus berasal dari lembaga pendidikan yan diakui oleh pemerintah. Artikel yang dapat diakses fulltext dalam format pdf. Kriteria jurnal yang direview adalah artikel jurnal penelitian berbahasa Indonesia dengan subjek anak remaja. 


\section{HASIL}

Terdapat sebelas artikel mengenai media promosi kesehatan dan efektivitas media dalam promosi kesehatan yang terbit pada jurnal nasional mulai tahun 2015 hingga tahun 2020. Seluruh artikel tersebut diterbitkan pada jurnal terindeks seperti SINTA, Google Scholar, Garuda, EBSCO, Crossref, DOAJ, Dimensions, IndonesiaOneSearch, IPI, BASE dan PKP Index. Pada hasil ditemukan bahwa media berperan dalam peningkatan pengetahuan.

Media promosi kesehatan yang digunakan sangat beragam seperti media animasi, media leaflet dengan media film, media video dengan media food model, hanya media leaflet saja, media cakram gizi, media motion video, media booklet serta buku cerita.
Berdasarkan 8 artikel yang dikaji, hasil dari gambaran pengetahuan remaja seluruhnya mengalami peningkatan skor, persentasi ataupun rata-rata (mean) setelah diberikan media promosi kesehatan yang dikumpulkan melalui tes oleh peneliti dengan menggunakan instrumen berupa kuesioner maupun pengamatan secara langsung terhadap responden.

Berdasarkan 3 artikel yang dikaji, hasil dari gambaran asupan zat besi remaja setelah diberikan media promosi kesehatan yakni sebanyak 1 artikel tidak mengalami peningkatan konsumsi/pola zat besi sama sekali, 1 artikel mengalami penurunan zat besi setelah diberikan media promosi kesehatan dan 1 artikel mengalami peningkatan skor, persentasi ataupun rata-rata (mean) asupan zat besi setelah diberikan media promosi kesehatan yang dikumpulkan melalui tes oleh peneliti dengan menggunakan instrumen berupa food recall 24 hours.

Tabel 1. Ringkasan Isi Jurnal

\begin{tabular}{|c|c|c|c|c|}
\hline No & Judul Artikel/Penulis & Jurnal/Terbit/Indeks & $\begin{array}{c}\text { Metode } \\
\text { Penelitian/Lokasi }\end{array}$ & Tujuan Dan Hasil \\
\hline 1 & $\begin{array}{l}\text { Pengaruh Intervensi } \\
\text { Penyuluhan Gizi } \\
\text { dengan Media Animasi } \\
\text { Terhadap Perubahan } \\
\text { Pengetahuan dan Sikap } \\
\text { Tentang Anemia pada } \\
\text { Remaja Putri (Syakir, } \\
\text { et al. 2018) }\end{array}$ & $\begin{array}{l}\text { Jurnal: Jurnal Argipa } \\
\text { Terbit: Vol.3 No.1 } \\
\text { Tahun } 2018 \\
\text { Index: SINTA, Google } \\
\text { Scholar, Crossref. }\end{array}$ & $\begin{array}{l}\text { Metode : Pre- } \\
\text { eksperimental one } \\
\text { group pretest- } \\
\text { posttest design } \\
\text { Sampel : } 300 \text { orang } \\
\text { Lokasi : SMA Kota } \\
\text { Bandar Lampung }\end{array}$ & $\begin{array}{l}\text { Tujuan : untuk mengetahui } \\
\text { pengaruh intervensi penyuluhan gizi } \\
\text { dengan media animasi terhadap } \\
\text { pengetahuan dan sikap tentang } \\
\text { anemia pada remaja putri. } \\
\text { Hasil : Pada pre-test nilai minimal } \\
\text { sebesar } 40 \text { dan maksimal } 90 \text { dengan } \\
\text { rata-rata } 69,88 . \text { Nilai post-test } \\
\text { minimal } 60 \text { dan maksimal } 95 \text { dengan } \\
\text { rata-rata } 77,70 \text {, terdapat peningkatan } \\
\text { sebesar } 7,9 \text { pada nilai rata-rata } \\
\text { subjek. Hasil penelitian } \\
\text { menunjukkan ada perubahan skor } \\
\text { pengetahuan dan sikap setelah } \\
\text { dilakukan intervensi dengan } \\
\text { menggunakan media animasi } \\
(p<0,05) \text { ananan }\end{array}$ \\
\hline 2 & $\begin{array}{l}\text { Efektivitas Media } \\
\text { Leaflet dan Film dalam } \\
\text { Peningkatan } \\
\text { Pengetahuan Pubertas } \\
\text { di SMP N 226 Pondok } \\
\text { Labu (Hadiwiardjo, et } \\
\text { al. 2020) }\end{array}$ & $\begin{array}{l}\text { Jurnal:Disease } \\
\text { Prevention and Public } \\
\text { Health Journal } \\
\text { Terbit: Vol.4 No.1 } \\
\text { Tahun 2018 } \\
\text { Index: SINTA, Google } \\
\text { Scholar, Crossref, LIPI, } \\
\text { Base, Sherpa,ISJD. }\end{array}$ & 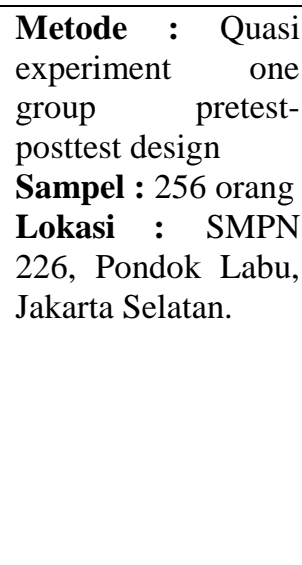 & $\begin{array}{l}\text { Tujuan : untuk mengetahui } \\
\text { efektivitas media leaflet dan media } \\
\text { film dalam peningkatan } \\
\text { pengetahuan pubertas di Sekolah } \\
\text { Menengah Pertama Negeri. } \\
\text { Hasil : Terdapat perbedaan } \\
\text { pengetahuan pubertas sebelum dan } \\
\text { sesudah diberi promosi kesehatan } \\
\text { dengan media film pada siswa }(p- \\
\text { value }<0,05) \text { dan terjadi peningkatan } \\
\text { median dari sebelum promosi } \\
\text { kesehatan yaitu } 86,67 \text { menjadi } 93,33 \\
\text { setelah diberi promosi kesehatan } \\
\text { dengan media film. }\end{array}$ \\
\hline 3 & 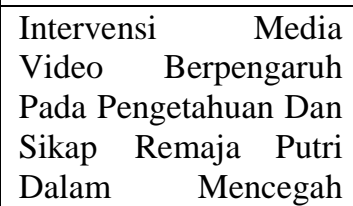 & $\begin{array}{l}\text { Jurnal:Aceh } \quad \text { Nutrition } \\
\text { Journal } \\
\text { Terbit: Vol.9 } \\
\text { Tahun } 2019\end{array}$ & $\begin{array}{lr}\text { Metode : } & \text { Quasi } \\
\text { experiment } & \text { with } \\
\text { control group design } \\
\text { Sampel : } 54 \text { orang }\end{array}$ & $\begin{array}{l}\text { Tujuan : untuk mengetahui } \\
\text { perbedaan pengetahuan dan sikap } \\
\text { remaja putri dalam pencegahan } \\
\text { kurang energi kronik (KEK) antara } \\
\text { yang diintervensi penyuluhan }\end{array}$ \\
\hline
\end{tabular}




\begin{tabular}{|c|c|c|c|c|}
\hline & $\begin{array}{l}\text { Kurang Energi Kronik } \\
\text { (Waryana, et al.2019). }\end{array}$ & $\begin{array}{l}\text { Index: Google Scholar, } \\
\text { Crossref, SINTA, } \\
\text { EBSCO, PKP Index, } \\
\text { University of Oxford }\end{array}$ & $\begin{array}{l}\text { Lokasi } \quad \text { : } \quad \text { Desa } \\
\text { Tridadi, Kabupaten } \\
\text { Sleman. }\end{array}$ & $\begin{array}{l}\text { dengan media video dan dengan } \\
\text { food model. } \\
\text { Hasil : Ada selisih skor pengetahuan } \\
\text { tentang pencegahan KEK pada } \\
\text { kedua kelompok tersebut sebesar } \\
\text { 1,07. Berdasarkan uji statistik(beda } \\
\text { ratarata) diperoleh nilai } \mathrm{p}=0,001 \\
(\mathrm{p}<0,05) \text {. Hal ini menunjukkan } \\
\text { bahwa ada perbedaan yang } \\
\text { signifikan nilai pengetahuan tentang } \\
\text { pencegahan KEK setelah diberikan } \\
\text { penyuluhan pada kedua kelompok. }\end{array}$ \\
\hline 4 & $\begin{array}{lr}\text { Pengaruh Promosi } \\
\text { Kesehatan Reproduksi } \\
\text { Remajar Terhadap } \\
\text { Pengetahuan dan Sikap } \\
\text { Siswa SMP Negeri 08 } \\
\text { Bitung (Karundeng, et } \\
\text { al. 2015) }\end{array}$ & $\begin{array}{lr}\text { Jurnal: Jurnal } & \text { Ilmiah } \\
\text { Bidan } & \\
\text { Terbit:Vol.3 } & \text { No.2 } \\
\text { Tahun 2015 } & \\
\text { Index: SINTA, Neliti, } \\
\text { Base, IOS, Google } \\
\text { Scholar, Garuda. }\end{array}$ & $\begin{array}{l}\text { Metode : } \\
\text { eksperimental one } \\
\text { group pretest- } \\
\text { posttest design } \\
\text { Sampel : } 63 \text { orang } \\
\text { Lokasi : SMP } \\
\text { Negeri } 08 \text { Bitung. }\end{array}$ & $\begin{array}{l}\text { Tujuan : } \begin{array}{r}\text { untuk menganalisis } \\
\text { pengaruh promosi } \\
\text { kesehatan }\end{array} \\
\text { reproduksi remaja terhadap } \\
\text { pengetahuan dan sikap siswa SMP } \\
\text { Hasil : Menunjukkan ada perubahan } \\
\text { nilai mean skor pengetahuan siswa } \\
\text { sebelum dan sesudah promosi } \\
\text { kesehatan 5,54 dengan p=0,0001; } \\
t_{\text {hitung-37,410 dan sikap siswa }} \\
\text { sebelum dan sesudah promosi } \\
\text { kesehatan } 6,46 \text { dengan p=0,0001 } \\
t_{\text {hitung-37,873 maka Ho ditolak Ha }} \\
\text { diterima. }\end{array}$ \\
\hline 5 & $\begin{array}{l}\text { Pengaruh Penggunaan } \\
\text { Media Cakram Gizi } \\
\text { terhadap pengetahuan } \\
\text { remaja mengenai } \\
\text { konsumsi buah dan } \\
\text { sayur (Mahmudah, et } \\
\text { al. 2020) }\end{array}$ & $\begin{array}{ll}\text { Jurnal:Ilmu } & \text { Gizi } \\
\text { Indonesia } & \\
\text { Terbit: Vol.3 No.2 } \\
\text { Tahun } 2020 \\
\text { Index: Google } & \text { Scholar, } \\
\text { Crossref, } & \text { SINTA, } \\
\text { EBSCO, LIPI. } & \end{array}$ & $\begin{array}{l}\begin{array}{l}\text { Metode : } \\
\text { experiment }\end{array} \begin{array}{r}\text { Quasi } \\
\text { one }\end{array} \\
\text { group pretest- } \\
\text { posttest design } \\
\text { Sampel : } 61 \text { orang } \\
\text { Lokasi : SMA } \\
\text { Muhammadiyah } 3 \\
\text { Yogyakarta }\end{array}$ & $\begin{array}{l}\text { Tujuan : Untuk mengetahui } \\
\text { pengaruh penggunaan media cakram } \\
\text { gizi terhadap pengetahuan remaja } \\
\text { mengenai konsumsi buah dan sayur. } \\
\text { Hasil : Nilai pengetahuan minimum } \\
\text { pada pretest dan posttest adalah } \\
46,67 \text { dan } 40,00 \text {, sedangkan nilai } \\
\text { maksimum baik pretest maupun } \\
\text { posttest sama yaitu } 93,33 \text {. Terdapat } \\
\text { peningkatan rerata nilai pengetahuan } \\
\text { dari } 68,30 \text { menjadi } 72,67 \text {. }\end{array}$ \\
\hline 6 & $\begin{array}{l}\text { Penyuluhan Anemia } \\
\text { Gizi dengan Media } \\
\text { Motion Video terhadap } \\
\text { Pengetahuan dan Sikap } \\
\text { Remaja Putri (Fitriani, } \\
\text { et al. 2019) }\end{array}$ & $\begin{array}{l}\text { Jurnal: Jurnal Kesehatan } \\
\text { Terbit: Vol.11 No. } 1 \\
\text { Tahun } 2019 \\
\text { Index: DOAJ, Google } \\
\text { Scholar, Garuda, SINTA, } \\
\text { Stat Counter }\end{array}$ & $\begin{array}{l}\begin{array}{l}\text { Metode : } \\
\text { experiment }\end{array} \begin{array}{r}\text { Quasi } \\
\text { one } \\
\text { group pretest- }\end{array} \\
\text { posttest design } \\
\text { Sampel : } 18 \text { orang } \\
\text { Lokasi : SMA Bina } \\
\text { Muda Cicalengka. }\end{array}$ & $\begin{array}{l}\text { Tujuan : untuk mengetahui } \\
\text { pengaruh penyuluhan anemia gizi } \\
\text { dengan media motion video terhadap } \\
\text { pengetahuan dan sikap sebelum dan } \\
\text { setelah intervensi pada remaja putri. } \\
\text { Hasil : Hasil penelitian ini } \\
\text { menunjukkan rata-rata pengetahuan } \\
\text { dan sikap anemia sebelum diberikan } \\
\text { penyuluhan anemia gizi adalah } 5.10 \\
\text { dan 23.19, setelah diberikan } \\
\text { penyuluhan meningkat menjadi } 8.71 \\
\text { dan 25.51. }\end{array}$ \\
\hline 7 & $\begin{array}{lr}\text { Pengaruh } & \text { Penggunaan } \\
\text { Media } & \text { Booklet } \\
\text { Terhadap Peningkatan } \\
\text { Pengetahuan Tentang } \\
\text { Kecukupan Energi } \\
\text { Remaja (Lendra, et al. } \\
2018 \text { ) }\end{array}$ & $\begin{array}{l}\text { Jurnal : Jumantik } \\
\text { Terbit: Vol.5 No.1 } \\
\text { Tahun } 2018 \\
\text { Index: PKP Index, } \\
\text { Google Scholar, Garuda, } \\
\text { SINTA, Crossref, } \\
\text { Moraree. }\end{array}$ & $\begin{array}{l}\begin{array}{l}\text { Metode : } \\
\text { experiment }\end{array} \begin{array}{r}\text { Quasi } \\
\text { one } \\
\text { group pretest- }\end{array} \\
\text { posttest design } \\
\text { Sampel : } 30 \text { orang } \\
\text { Lokasi : SMAN 1 } \\
\text { Pontianak. }\end{array}$ & 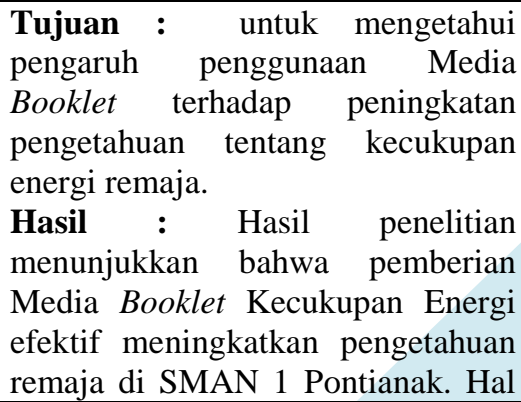 \\
\hline
\end{tabular}




\begin{tabular}{|c|c|c|c|c|}
\hline & & & & 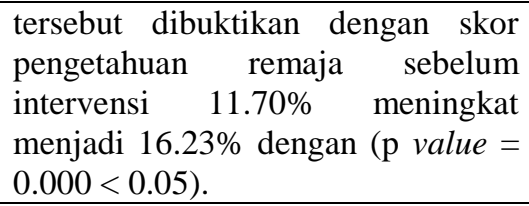 \\
\hline 8 & 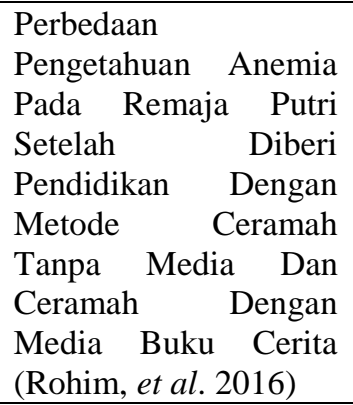 & $\begin{array}{l}\text { Jurnal : Jurnal } \\
\text { Kesehatan } \\
\text { Terbit: Vol.1 No.2 } \\
\text { Tahun } 2016 \\
\text { Index: DOAJ, Google } \\
\text { Scholar, Garuda, } \\
\text { SINTA. }\end{array}$ & $\begin{array}{l}\text { Metode : } \\
\text { experiment }\end{array} \begin{array}{r}\text { with } \\
\text { control group design } \\
\text { Sampel : } 39 \text { orang } \\
\text { Lokasi : SMP } \\
\text { Muhammadiyah } 1 \\
\text { Surakarta. }\end{array}$ & $\begin{array}{l}\text { Tujuan : mengetahui perbedaan } \\
\text { pengetahuan anemia dengan metode } \\
\text { ceramah tanpa media dan ceramah } \\
\text { menggunakan buku cerita. } \\
\text { Hasil : Pendidikan metode ceramah } \\
\text { dengan buku cerita memberikan } \\
\text { hasil yang lebih baik } 11,49 \text { lebih } \\
\text { tinggi dibandingkan dengan } \\
\text { ceramah tanpa media. }\end{array}$ \\
\hline 9 & $\begin{array}{l}\text { Pengaruh Edukasi Gizi } \\
\text { Terhadap Pengetahuan } \\
\text { Gizi dan Asupan } \\
\text { Energi, Protein dan } \\
\text { Besi pada Remaja } \\
\text { (Pakhri, } \text { et al. 2020) }\end{array}$ & $\begin{array}{l}\text { Jurnal: Media } \\
\text { Kesehatan } \\
\text { Terbit: Vol.15 No.1 } \\
\text { Tahun } 2020 \\
\text { Index: Google Scholar, } \\
\text { ISJDNeo, SINTA, IPI, } \\
\text { Crossref, Neliti, Base, } \\
\text { IOS }\end{array}$ & $\begin{array}{l}\begin{array}{l}\text { Metode : } \\
\text { experiment }\end{array} \begin{array}{r}\text { Quasi } \\
\text { group pretest- }\end{array} \\
\text { posttest design } \\
\text { Sampel : } 34 \text { orang } \\
\text { Lokasi : SMP } \\
\text { Negeri 35 Makassar. }\end{array}$ & 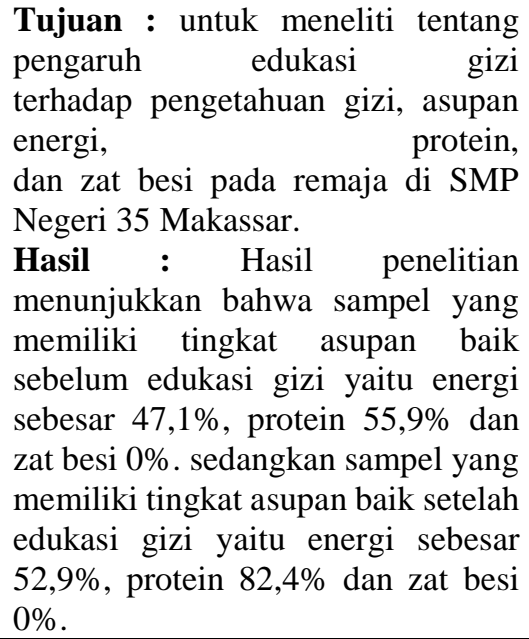 \\
\hline 10 & 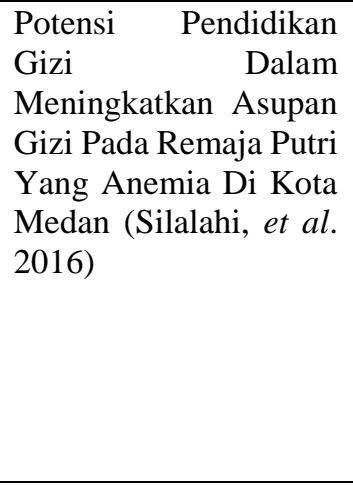 & $\begin{array}{l}\text { Jurnal: Kesmas } \\
\text { Terbit: Vol.11 No. } 2 \\
\text { Tahun } 2016 \\
\text { Index: DOAJ, Crossref, } \\
\text { Google Scholar, } \\
\text { EBSCO, IPI, ISJD, } \\
\text { SINTA, Neliti, CABI, } \\
\text { SJR }\end{array}$ & 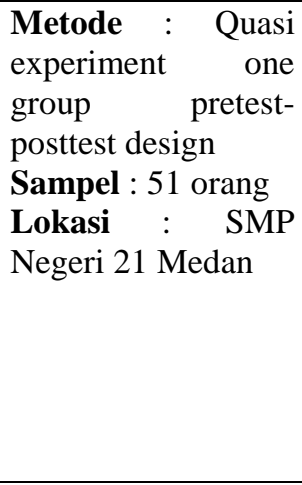 & $\begin{array}{l}\text { Tujuan : menganalisis pengaruh } \\
\text { pendidikan gizi terhadap } \\
\text { pengetahuan gizi dan konsumsi zat } \\
\text { gizi remaja putri. } \\
\text { Hasil : Hasil menunjukkan bahwa } \\
\text { skor pengetahuan gizi meningkat } \\
\text { dari } 62,39 \pm 12,05 \text { poin menjadi } \\
72,31 \pm 17,01 \text { poin. Asupan gizi } \\
\text { (protein, vitamin C, vitamin A, asam } \\
\text { folat, besi, zink, tembaga) } \\
\text { mengalami penurunan sesudah } \\
\text { intervensi. }\end{array}$ \\
\hline 11 & $\begin{array}{lr}\text { Efektifitas } & \text { Edukasi } \\
\text { Gizi } & \text { Terhadap } \\
\text { Perbaikan Asupan Zat } \\
\text { Besi Pada Remaja Putri } \\
\text { (Marfuah, } \text { et al. 2016) }\end{array}$ & $\begin{array}{l}\text { Jurnal: PROFESI } \\
\text { Terbit: Vol.14 No. } 1 \\
\text { Tahun } 2016 \\
\text { Index:Crossref, Google } \\
\text { Scholar, DOI, Mendeley, } \\
\text { IPI, DOAJ, SINTA, } \\
\text { Dimensions. }\end{array}$ & 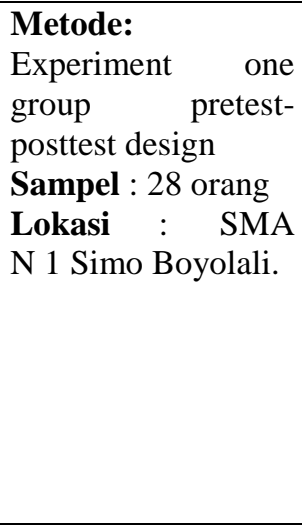 & $\begin{array}{l}\text { Tujuan : untuk mengetahui } \\
\text { efektifitas edukasi gizi terhadap } \\
\text { asupan zat besi pada remaja putri. } \\
\text { Hasil : Hasil penelitian ini adalah } \\
\text { mayoritas asupan zat besi remaja } \\
\text { putri sebelum diberikan edukasi gizi } \\
\text { termasuk kategori kurang }(82,14 \%) \\
\text { dan setelah diberikan edukasi gizi } \\
\text { mayoritas kategori cukup }(75 \%) \text {. } \\
\text { Pemberian edukasi gizi efektif } \\
\text { meningkatkan rata-rata asupan zat } \\
\text { besi pada remaja putri sebesar } 15,5 \\
\text { mg (p value }=0.000) \text {. }\end{array}$ \\
\hline
\end{tabular}




\section{PEMBAHASAN}

Dari jumlah keseluruhan literatur yakni 11 artikel yang dikaji, sebanyak 8 artikel dengan tema atau topik yang berhubungan dengan efektivitas penggunaan media promosi kesehatan terhadap pengetahuan pada remaja seluruhya menyatakan bahwa dalam penelitiannya media promosi kesehatan berpengaruh dalam meningkatkan pengetahuan remaja dengan berbagai media yang berbeda yang digunakan oleh peneliti dilihat dari nilai signifikansi atau $\mathrm{p}<0,05$ yang berarti memiliki efektivitas yang lebih baik (Syakir, et al. 2018; Hadiwiardjo, et al. 2020; Waryana, et al. 2019; Karundeng, et al. 2015; Mahmudah, et al. 2020; Fitriani, et al. 2019; Lendra, et al. 2018; Rohim, et al. 2016).

Media promosi kesehatan yang digunakan sangat beragam seperti media animasi, media leaflet dengan media film, media video dengan media food model, hanya media leaflet saja, media cakram gizi, media motion video, media booklet serta buku cerita.

Meningkatkan pengetahuan perlu adanya pemberian informasi yang menurut WHO merupakan salah satu strategi untuk memdapatkan perubahan perilaku. Salah satu upaya pemberian informasi adalah dengan menggunakan media promosi kesehatan. Media promosi kesehatan akan sangat membantu agar pesan-pesan yang disampaikan dalam promosi kesehatan dapat diberikan dengan jelas sehingga sasaran dapat menerima pesan dengan jelas dan tepat yang dapat terlihat dengan terjadinya peningkatan nilai pengetahuan (Notoaatmodjo, 2010).

Dari 3 artikel dengan tema atau topik yang berhubungan dengan efektivitas penggunaan media promosi kesehatan terhadap pola konsumsi zat besi pada remaja, sebanyak 2 artikel menyatakan bahwa dalam penelitiannya media promosi kesehatan tidak berpengaruh dalam meningkatkan pengetahuan remaja dilihat dari nilai signifikansi atau $\mathrm{p}>0,05$. Sedangkan 1 artikel menyatakan bahwa dalam penelitiannya media promosi kesehatan terdapat pengaruh media promosi kesehatan dalam meningkatkan pengetahuan remaja dilihat dari nilai signifikansi atau $\mathrm{p}<0,05$ yang berarti memiliki efektivitas yang lebih baik.

Hal ini menunjukkan bahwa pendidikan gizi yang diberikan tidak mampu mengubah pola makan remaja putri dikarenakan penyediaan makanan bergantung pada penyediaan makanan yang disediakan oleh orang tua di rumah. Orang tua berperan besar dalam mengatur kebiasaan makan anaknya. Meskipun anak mendapatkan pendidikan gizi, bila orang tuanya tidak mendapatkan pendidikan gizi, maka konsumsi makanan cenderung tidak akan berubah. Selain itu, tingkat sosial ekonomi keluarga juga memengaruhi ketersediaan makanan di tingkat rumah (Silalahi, 2016).

Penggunaan media promosi kesehatan dalam kegiatan pembelajaran tidak hanya sekedar sebagai alat bantu, melainkan sebagai pembawa informasi atau pesan yang ingin disampaikan yang dapat memberikan dampak positif bagi responden atau pendengarnya. Oleh karena itu, media promosi kesehatan yang dikembangkan merupakan media yang menjanjikan untuk mendukung perubahan di dalam kehidupan anak remaja. Peneliti selanjutnya juga dapat lebih terfokus dalam upaya pengoptimalan perkembangan media promosi kesehatan untuk meningkatkan pengetahuan, perilaku dan sikap.

Upaya untuk meningkatkan media promosi kesehatan telah dilakukan oleh pemerintah yang menjadi salah satu program pemerintah dibawah koordinasi Kementerian Kesehatan. Beberapa contoh promosi kesehatan yang sering dilakukan pemerintah dalam bentuk video yaitu Perilaku Hidup Bersih dan Sehat (PHBS), Cuci Tangan Pakai Sabun (CTPS), Mengkonsumsi makanan sehat seperti sayur dan buah, Mengkonsumsi makanan Gizi Seimbang. Pemerintah telah mengeluarkan beberapa kebijakan untuk mendukung promosi kesehatan dalam Keputusan Menteri Kesehatan Republik Indonesia Nomor: 1193/MENKES/SK/X/2004 tentang Kebijakan Nasional Promosi Kesehatan Menteri Kesehatan Republik Indonesia.

\section{KESIMPULAN}

Berdasarkan penjelasan diatas dapat disimpulkan bahwa terdapat sebelas artikel yang relevan dan dapat dilakukan review. Dari artikel tersebut menunjukkan strategi untuk meningkatkan pengetahuan dan pola konsumsi remaja adalah promosi kesehatan dengan menggunakan berbagai media promosi kesehatan seperti media animasi, media leaflet dengan media film, media video dengan media food model, hanya media leaflet saja, media cakram gizi, media motion video, media booklet serta buku cerita.

Pemerintah sebaiknya mulai berinovasi menciptakan media-media dalam promosi kesehatan sesuai dengan perkembangan zaman agar masyarakat tidak bosan dengan media promosi kesehatan yang ada. Banyak peneliti yang sudah mulai berinovasi dalam menciptakan media promosi kesehatan dari mulai media cetak, media berbasis audio-visual,media berbasis android dan internet yang dapat membantu media promosi kesehatan ini diterapkan secara berkelanjutan.Sehingga, peneliti lainnya diharapkan dapat melakukan penelitian lanjutan tentang efektivitas 
penggunaan media promosi kesehatan terhadap pengetahuan dan pola konsumsi zat besi pada remaja.

\section{DAFTAR PUSTAKA}

Institute of Medicine (IOM). 2004. Healthy Literacy: A Prescription to End Confusion. Washington,DC: National Academies Press p.32-37.

Juliani, D. 2017. Gambaran Kebiasaan Makan Dan Status Gizi Remaja SMA Harapan Mandiri Medan Tahun 2017. Skripis Sarjana. Fakultas Kesehatan Masyarakat. Universitas Sumatera Utara Medan.

Kadir, A. 2016. Kebiasaan Makan dan Gangguan Pola Makan Serta Pengaruhnya Terhadap Status Gizi Remaja. Jurnal Publikasi Pendidikan, Vol VII (1) hal 49-55.

Kesuma, Citra. 2012. Anemia Gizi, Masalah dan Pencegahannya. Jakarta: Kalika.

Kholid, Ahmad. 2012. Promosi Kesehatan Dengan Pendekatan Teori Perilaku, Media, Dan Aplikasinya. Jakarta: PT. RajaGrafindo Persada.

Marmi, 2013. Gizi dalam Kesehatan Reproduksi. Yogyakarta: Pustaka Pelajar

Notoatmodjo,S. 2010. Promosi Kesehatan Teori Dan Aplikasi. Jakarta: Rineka Cipta

Ningsih, Silawati. 2018. Pengaruh Edukasi Pedoman Gizi Seimbang Terhadap Pengetahuan Dan Sikap Remaja Putri Kukus. Jurnal Of Midwifer Science. Stikes Payung Negeri Pekanbaru.

Peraturan Menteri Kesehatan Republik Indonesia Nomor 44/Permenkes/2018 Tentang Penyelenggaraan Promosi Kesehatan Rumah Sakit

Sediaoetama, AD. 2000. Ilmu Gizi. Jilid I Cetakan Keempat. Dian Rakyat : Jakarta

Silalahi V, aritonang E, Ashar T. 2016. Potensi Pendidikan Gizi dalam Meningkatkan Asupan gizi pada Remaja Putri di Kota Medan. Jurnal Kesehatan Masyarakat. http://journal.unnes.ac.id/nju/index.php/kemas

Suarjana, Nyoman. 2017. Hubungan Antara Tingkat Pengetahuan Dengan Sikap Remaja Putri Terhadap Pentingnya Konsumsi Makanan Yang Mengandung Zat Besi Saat Menstruasi DI SMAN 2 Tabanan Tahun 2013. Program Studi Kesehatan Masyarakat. Universitas Dhyana Pura.

Suryani Desri, dkk. 2015. Analisis Pola Makan Dan Anemia Gizi Besi Pada Remaja Putri Kota Bengkulu. Jurnal Kesehatan Masyarakat Andalas, Vol.10, No.1 Oktober 2015.

Word Health Organization (WHO). 2014. Obesity and Overweight.http://who.int/mediacenter/factsheets/f s311/en/ diakses pada Januari 2015 